\title{
Drying of algae by various drying methods
}

\section{Bheda, B. ${ }^{\text {a }}$ Shinde, M. ${ }^{\mathrm{b}}$; Ghadge, R. ${ }^{\mathbf{b}}$; Thorat, B N. ${ }^{{ }^{*}}$}

a Advanced Drying Laboratory, Department of Chemical Engineering, Institute of Chemical Technology (formerly UDCT), Mumbai, India

b Reliance Industries Limited, India

*E-mail of the corresponding author: bn.thorat@ictmumbai.edu.in

\begin{abstract}
Algae drying was carried out using Vacuum Tray Dryer and an Innovative Solar Conduction Dryer. Algae was dried in a Vacuum Tray Dryer at $60^{\circ} \mathrm{C}$ under varied pressure conditions and makes use of specially designed double condenser system. The open sun drying and solar conduction dryer (SCD) was also used for algae drying. Comparison between open sun drying and solar conduction dryer were done and it was found that the solar conduction dryer gives high performance than the open sun drying. It was also found that, the conductive heat transfer mode plays a crucial role in the solar conduction dryer.
\end{abstract}

Keywords: Vaccum Dryer; Solar Conduction Dryer; Algal Drying. 


\section{Introduction}

Algae is a potential source of high-value products such as pigments, nutraceuticals, and protein-rich biomass as food supplements. Microalgae have the following advantages over terrestrial plants:

1. Microalgae has less growth in fresh water than saline or contaminated water.

2. Microalgae has less competition with food for arable lands but can be cultured in seas or in ponds or barrain lands ${ }^{[1]}$.

3. Microalgae can grow faster and also accumulate oil more efficiently than higher plants and oilseed crops ${ }^{[2,3]}$.

4. Microalgae can also produce valuable raw materials which are its coproducts (e.g., proteins, pigments, unsaturated fatty acids, carotenoids, and vitamin) ${ }^{[4]}$, used in the animal feed, food, cosmetics, and pharmaceutical industries.

5. Microalgae can convert $\mathrm{CO}_{2}$ into biomass with a high efficiency of $\mathrm{CO}_{2}$ utilization ${ }^{[5,6]}$. In general, $1.83 \mathrm{~kg} \mathrm{CO} 2$ consumed gives $1 \mathrm{~kg}$ of dry biomass of $\mathrm{CO}_{2}{ }^{[3]}$

Production of these high-value products from algae requires dry algal biomass with moisture less than $10 \%{ }^{[7]}$. Drying of algae is also essential for storage since harvested algae slurry is perishable and can spoil within a short time. However, microalgae in cultivated medium has low biomass concentration $(0.1-1 \% \mathrm{w} / \mathrm{w})$ and mechanical dewatering of algae in the cultivated medium can produce algae slurry having $20-30 \% \mathrm{w} / \mathrm{w}$ algal biomass ${ }^{[8,9]}$.

In this paper we shall be going through the various drying methods that have been attempted and the drying kinetics comparison study being carried out.

\section{Materials and Methods}

The harvested and dewatered algal biomass was obtained from Reliance Industries Limited. The centrifuged algae was collected in a can and transported to Institute of Chemical Technology, Mumbai, India and stored in the refrigerator at $4{ }^{\circ} \mathrm{C}$ until the drying experiments to prevent putrefaction. Before experiments, the slurry was brought back to ambient conditions. Trials were conducted in a Teflon coated plate of dimensions $21 \mathrm{~cm} \mathrm{x}$ $27 \mathrm{~cm}$ x $5 \mathrm{~cm}$. Trials conducted in Vacuum Tray Dryer and Solar Conduction Dryer. 


\subsection{Vacuum Tray Dryer}

It is a conventional vacuum tray dryer manufactured by Salvis Lab, which originally had a single condenser for condensing the vapours generated in the dryer. The operating temperature was $60^{\circ} \mathrm{C}$, hence the single condenser was inefficient in condensing and therefore a second condenser was added to it. The condensers were attached to a chiller whose temperature was maintained at $4^{\circ} \mathrm{C}$. The condenser was attached to a measuring cylinder, where the volume collected is measured. A flask containing silica gel was placed between the vacuum pump and cylinder, which acted a water trap, to prevent the uncondensed water from entering into the vacuum pump. The sample was dried over a pressure range of 30-50 mbar.

The samples were weighed and taken in the Teflon coated plate and kept for drying. The tray dryer and chiller were first allowed to attain the desired temperature of $60^{\circ} \mathrm{C}$ and $4{ }^{\circ} \mathrm{C}$ respectively. The sample was then loaded to the dryer and a vacuum pressure applied. The water collected in the measuring cylinder was noted at a regular interval of 10 minutes. However, the rate of drying drastically reduces after 8 hours, and the water collected in the measuring cylinder barely increases by a milliliter even after 30 minutes.

\subsection{Solar Conduction Dryer}

An innovative Solar Conduction Dryer (WO2014097307A1) ${ }^{[10]}$ was used for drying the sample. "The dryer comprises a radiation absorbing heat conducting surface, and a convection channel formed by a radiation controlling cover over the conducting surface" ${ }^{[10]}$. The solar drying experiment took place in Mumbai $\left(19.0239^{\circ} \mathrm{N}, 72.8575^{\circ} \mathrm{E}\right)$, India. The sample was loaded in a Teflon coated plate, weighed and kept inside the dryer, whose loss in weight was measured at a regular interval of 30 minutes. The other parameters that were measured and noted included the surface temperature of algae, surface temperature of the conduction plate and the atmospheric temperature using an infrared thermometer gun. Experiments were carried out between 09:00 hours and 16:00 hours on sunny days in the month of December 2017. At the end of the day (16:00 hours), the partially dried sample was covered with an aluminum foil and kept inside a drawer, for continuing the drying study the subsequent days. The drying experiment was continued till no change in weight was observed.

\section{Mathematical Models}

\subsection{Thin-layer Drying Model}

The thin-layer model is usually represented by the equation in terms of drying parameters to characterize the changes of the mean moisture content of food product during drying. 
The parameters that account for the combined effect of various transport phenomena in the drying process can be determined from the graphical method ${ }^{[11-12]}$. It can be expressed as:

$$
\phi=k_{0} \exp (-k t)
$$

where $\mathrm{k}_{0}$ and $\mathrm{k}$ represent the lag factor and drying constant of food product, respectively. The moisture diffusion coefficient, $\mathrm{D}_{\text {eff }}$ can be obtained from the following expression:

$$
D_{\text {eff }}=k \frac{L_{d}^{2}}{\mu_{1}^{2}}
$$

Where $L_{d}$ is the moisture diffusion path and $\mu_{1}$ is the characteristic parameter which can be obtained from the equation:

$$
\mu_{1}^{2}=\left(\mu_{1}\right)_{\infty}^{2} \frac{1}{1+\frac{A_{1}}{B i_{m}{ }^{p}}}
$$

where $B i_{m}$ represents the Biot number for mass transfer. The $\left(\mu_{1}\right)_{\infty}$ is the value of $\mu_{1}$ at $B i_{m}=$ $\infty$. The values of the constants $\left(\mu_{1}\right)_{\infty}=1.5708 ; \mathrm{A}_{1}=2.24 ; \mathrm{p}=1.02$, considering the algae to be a slice inside the plate. The Biot number can be obtained in terms of lag factor, $\mathrm{k}_{0}$ of drying characteristic curve using following relation ${ }^{[13]}$ :

$$
B i_{m}=\frac{5.132 \ln k_{0}}{1-3.948 \ln k_{0}}
$$

Knowing the value of $D_{\text {eff }}$, the convective mass transfer coefficient, $h_{m}$ can be calculated from the standard relation

$$
h_{m}=B i_{m} \frac{D_{e f f}}{L_{d}}
$$

The characteristic parameters $\mu_{1}$ and Biot number $\mathrm{Bi}_{\mathrm{m}}$ computed from respective Eqs. (3) and (4) are used in $\mathrm{D}_{\text {eff }}$ and $\mathrm{h}_{\mathrm{m}}$ estimation.

\section{Results and Discussion}

Figure 1 shows the dimensionless moisture content against drying time for the repeated experiments under a varied vacuum pressure of 30 millibar and 50 millibar in the vacuum tray dryer having an initial weight of $200 \mathrm{gm}$ at $60^{\circ} \mathrm{C}$. 


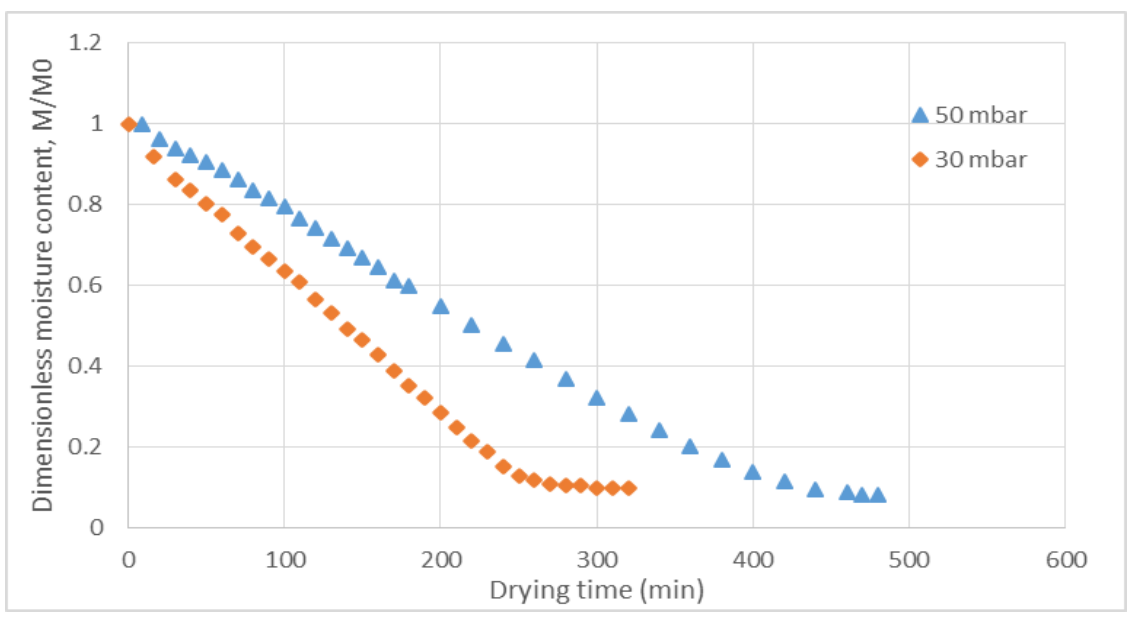

Figure 1. Variation in drying time with the change in vacuum applied

Table 1. Results of mass transfer co-efficients ( $D_{\text {eff }}$ and $\left.h_{m}\right) \&$ Biot number $\left(B i_{m}\right)$ for the 30 mbar and 50 mbar pressure.

\begin{tabular}{llc}
\hline & $\mathbf{3 0} \mathbf{~ m b a r}$ & $\mathbf{5 0 ~ m b a r}$ \\
\hline Biot Number & $1.435 \times 10^{-4}$ & $8.951 \times 10^{-5}$ \\
$\mathrm{D}_{\text {eff }}\left(\mathrm{m}^{2} / \mathrm{s}\right)$ & $9.451 \times 10^{-8}$ & $8.043 \times 10^{-8}$ \\
$\mathrm{~h}_{\mathrm{m}}(\mathrm{m} / \mathrm{s})$ & $2.296 \times 10^{-4}$ & $1.074 \times 10^{-4}$ \\
\hline
\end{tabular}

As it can be seen that by reducing the vacuum pressure from 50 millibar to 30 millibar, the drying time reduces and hence there is an increase in the drying rate. This fact is quantitatively reflected in the values obtained in Table 1.

Figure 2 shows the dimensionless moisture content against drying time for the open sun and solar conduction dryer for 200 gm algae slurry. As expected, solar conduction dryer gives higher performance than the solar conduction dryer. Solar conduction dryer takes less time than the open sun drying to achieve the required moisture content. Effective diffusivity $\left(D_{\text {eff }}\right)$, mass transfer coefficient $\left(\mathrm{h}_{\mathrm{m}}\right)$ and mass transfer Biot number $\left(\mathrm{Bi}_{\mathrm{m}}\right)$ values are depicted in Table 2. These values suggests that the solar conduction dryer gives higher performance than the open sun drying. 


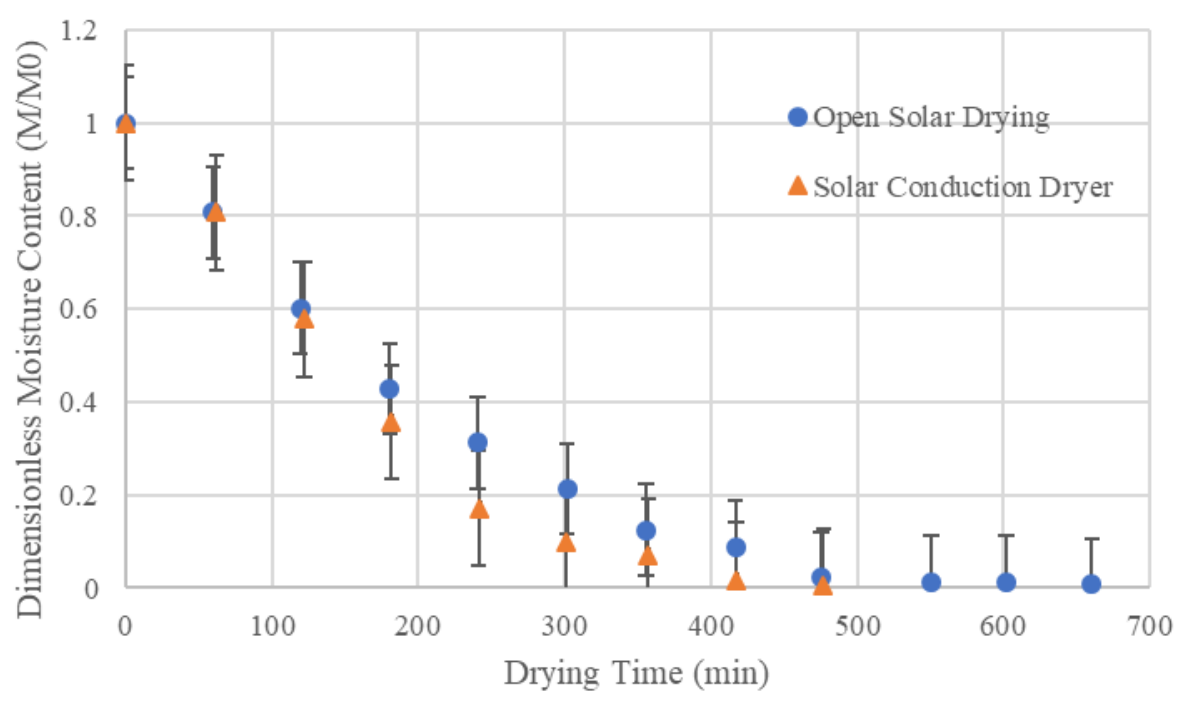

Figure 2. Comparison between the performance between open sun drying and solar conduction dryer for algae drying

Table 2. Results of mass transfer co-efficients ( $D_{\text {eff }}$ and $\left.h_{m}\right) \&$ Biot number $\left(B i_{m}\right)$ for open sun drying and Solar Conduction Drying.

\begin{tabular}{lll} 
& \multicolumn{2}{c}{ drying and Solar Conduction Drying. } \\
\hline & Solar Conduction Dryer & Open sun drying \\
\hline Biot Number & $5.517 \times 10^{-5}$ & $6.56 \times 10^{-5}$ \\
$\mathrm{D}_{\text {eff }}\left(\mathrm{m}^{2} / \mathrm{s}\right)$ & $1.355 \times 10^{-7}$ & $1.24 \times 10^{-7}$ \\
$\mathrm{~h}_{\mathrm{m}}(\mathrm{m} / \mathrm{s})$ & $8.826 \times 10^{-5}$ & $8.04 \times 10^{-5}$ \\
\hline
\end{tabular}

\section{Conclusions}

Algae drying was done by using various methods such as vacuum, open sun drying and solar conduction dryer. Vacuum drying suggests that, by reducing the pressure there was reduction in the drying time. At low pressure, the value of effective diffusivity and mass transfer coefficient were higher. Comparison between open sun drying and solar conduction dryer was done. It was found that, the performance for solar conduction dryer was higher than the open sun drying. The performance was checked on the basisi of effective diffusivity and mass transfer coefficient. Comparison between the solar conduction dryer and vaccum dryer suggests that the time required for Solar Conduction Drying is longer than Vacuum Tray Drying, however the operation cost for Solar Conduction Drying is negligible. 


\section{References}

[1] Rubin, E. S.; Mantripragada, H.; Marks, A.; Versteeg, P.; Kitchin, J.; The outlook for improved carbon capture technology, Progress in Energy and Combustion Science, 38(5), 630-671 (2012).

[2] Spolaore, P.; Joannis-Cassan, C.; Duran, E.; Isambert, A.; Commercial applications of microalgae, Journal of Bioscience and Bioengineering, 101(2), 87-96 (2006).

[3] Yusuf, C.; Biodiesel from microalgae, Biotechnology Advances, 25(3), 294-306 (2007).

[4] Scott, S. A.; Davey, M. P.; Dennis, J. S; Horst, I.; Lea-Smith, D. J.; Smith, A. G.; Biodiesel from algae: Challenges and prospects, Current Opinion in Biotechnology. 21(3), 277-286 (2010).

[5] Shelef, G.; Sukenik, A.; Green, M. Microalgae harvesting and processing: a literature review, (0), (1984).

[6] Khan, S. A.; Rashmi.; Hussain, M. Z.; Prasad, S.; Banerjee, U. S.; Prospects of biodiesel production from microalgae in India, Renewable and Sustainable Energy Reviews, 13(9), 2361-2372 (2009).

[7] Brennan, L.; Owende, P.; Biofuels from microalgae-A review of technologies for production, processing, and extractions of biofuels and co-products. Renewable and Sustainable Energy Reviews 14, 557-577 (2010)

[8] Hannon, M.; Gimpel, J.; Tran, M.; Rasala, B.; Mayfield, S.; Biofuels from algae: challenges and potential, Biofuels, 1(5), 763-784 (2010).

[9] Bhujade, R.; Chidambaram, M.; Kumar, A.; Sapre, A; Algae to Economically Viable Low-Carbon-Footprint Oil, Annual Review of Chemical and Biomolecular Engineering, 8(1), 335-357 (2017).

[10] Michael, H.; Javier, G.; Miller, T.; Beth, R.; Stephen, M.; Biofuels from algae: challenges and potential. Biofuels 1(5), 763-784 (2010).

[11] Tidke, V.; Thorat, B.N.; Kokate, S.; Solar Dryer, WO2014097307A1, (2012).

[12] Dincer, I.; Dost, S; A modelling study for moisture diffusivities and moisture transfer coefficients in drying of solid objects. International journal of energy research 20, 531539 (1996).

[13] Tripathy, P.P.; Kumar, S; A methodology for determination of temperature dependent mass transfer coefficients from drying kinetics: Application to solar drying. Journal of Food Engineering 90, 212-218 (2009).

[14] Pflug, L.J; Blaisdell, J. L; Methods of analysis of precooling data. ASHRAE journal 5, 33-40 (1963). 